\title{
The Emotion of Awe and Perception of Destination to Influence Tourists' Satisfaction
}

\author{
Dong Lu' ${ }^{1}$, Ye Tian² \\ ${ }^{1}$ School of Business, Sichuan Normal University, Chengdu, China \\ ${ }^{2}$ School of Economics and Management, Southwest Jiaotong University, Chengdu, China \\ Email: dlu@sicnu.edu.cn, ye.tian@my.swjtu.edu.cn
}

Received 10 September 2015; accepted 13 October 2015; published 16 October 2015

Copyright (C) 2015 by authors and Scientific Research Publishing Inc.

This work is licensed under the Creative Commons Attribution International License (CC BY). http://creativecommons.org/licenses/by/4.0/

c) (i) Open Access

\begin{abstract}
This study aimed to explain tourist satisfaction by using an integrated model that incorporated cognitive and affective perspectives. Questionnaires data were collected from 385 participants in Tibet and the conceptual model was verified by using Structural Equation Modeling. The results showed that, from the cognitive viewpoint, the perception of the natural environment was the key factor to influence tourists' satisfaction; from the affective viewpoint, both the perception of the natural environment and the perception of the religious atmosphere were the factors to influence tourists' satisfaction. The perceived value of the destination (cognitive factor) and experience of the emotion of awe (affective factor) also influenced tourists' satisfaction. Additionally, the findings of this study showed that the emotion of awe was the mediator between the perceived value of the destination and the tourists' satisfaction. In a summary, this study presented a theoretical framework that was based on the dual perspectives of cognition and affection to expand the existing research and provided a comprehensive and reasonable interpretation of tourists' satisfaction.
\end{abstract}

\section{Keywords}

Cognitive-Affective Nature, Emotion of Awe, Perceived Value, Satisfaction

\section{Introduction}

Cronin et al. indicated that satisfaction was a key construct in consumer behavior research, which influenced both the decision to consume and the retention after consumption [1]. Numerous of tourism researches stated that in the tourism context, many external factors such as attributes of the environment were the antecedents of the tourists' 
satisfaction [2]. Although the antecedents of satisfaction included multiple aspects [3], most of previous studies about the relation between the attributes of a tourism destination and the tourists' satisfaction had only adopted a single perspective, either cognitive or affective view. However, tourism was a complex experiential activity, and tourists not only process cognitive information but also experience emotions which were provoked by the outside environment [4]. Therefore, both cognitive and affective factors should be considered when examining the relation between the attributes of a tourism destination and tourists' satisfaction.

This study aimed to use both cognitive and affective constructs to determine how tourists' satisfaction was generated. The cognitive point of view incorporated the rational processing of information regarding the tourism destination, and examined how the perceived value of the destination influenced the satisfaction. The affective point of view incorporated the awe that tourists felt when they encountered magnificent mountains, a grand vista, or other great scenes and investigated how emotion of awe positively promoted tourists' satisfaction [5]. Data from tourists who had Tibet travel experience were collected and tested in the model to verify how cognitive and affective constructs influenced tourists' satisfaction. Furthermore, the model proposed in this study explained the mediating effect of the perceived value of the destination and the emotion of awe on the relation between the tourism environment and tourists' satisfaction.

\section{Literature Review}

\subsection{Past Studies Performed From a Single Perspective}

Decrop demonstrated that there are two mainstream paradigms used to research tourists' satisfaction [6]. Most studies on this topic are based on the perspective of either cognition or affection. From the perspective of cognition, exogenous variables such as the tourism destination image and service quality are the driving factors behind tourists' satisfaction [7]. Other studies also found that the perceived value of the destination can be the cause of tourists' satisfaction [8].

Early researches conducted from the perspective of affection focused predominantly on the simple relation between emotions and satisfaction. For example, Wirtz et al. stated that emotions can moderate satisfaction [9], and Phillips and Baumgartner reported that both positive and negative emotions affected satisfaction and proposed the expectancy disconfirmation model [10]. Subsequent researches have focused on the antecedents of these emotions, and the outcomes associated with these emotions, of which a full path is constructed from environmental factors to satisfaction. For example, Walsh et al. found that environmental factors first stimulate emotion, and then continue to impact on satisfaction. In a study about travel to festivals [11], Lee et al. reported that environmental characteristics such as food quality and program content affected the tourists' emotions, and these emotions mediated the relationship between environmental characteristics and tourists' satisfaction [12].

To sum up, previous studies merely considered a single perspective (cognition or affection) to explain the mechanism of how the satisfaction is generated. However, there is lack of research to investigate the causes of tourists' satisfaction by using both the cognition and affection viewpoints.

\subsection{The Cognitive-Affective Nature of Satisfaction}

Psychologists believed that human behavior is affected simultaneously by cognitive and affective factors. Piaget first proposed that cognition and emotion are interrelated [13]. Piaget believed that although the cognitive and emotional ways about information processing are distinct, there are some interactions between them, and stated that, "cognition is like the motor while emotion is like the gasoline; the gasoline enables the motor to run well but does not change the structure of the car". Lemerise and Arsenio provided a detailed explanation of the cognitive and affective information processing involved in decision-making [14]. They showed that individual judgment of value is a cognitive process, but that individual emotions can be involved as affective elements, and that decision-making behavior depends on the interaction between the cognitive and affective processes. In an experimental study, Gray et al. found that when the cognitive and affective processes are wholly integrated, they work together to control the individual behavior [15].

In recent years, marketing and tourism studies have begun to pay attention to the cognitive-affective nature of behavior. In research on consumer experience and satisfaction, Mano and Oliver proposed that cognitive and affective factors can be used as antecedents of satisfaction [16]. In terms of tourism, some researchers have defined tourist satisfaction using both the cognitive and affective points of view, stating that it results from the expression 
of cognitive judgment and emotional experience that arises from the tourists' perception of the environment [17]. Bigne et al. studied tourists at theme parks and reported that when tourists perceived an ambient atmosphere, the tourists would produce cognitive information processing and emotional expression, and the tourists' satisfaction were influenced by the tourists' cognitive information processing and emotional expression [18]. Empirical research on Spanish tourists also supports the cognitive-affective nature on tourists' satisfaction [19]. Therefore, in this study, we build an integrated model to study the mechanism with the cognitive-affective nature, and we specifically focused on the dual path of "Perceived value of the destination" in cognition and "The emotion of awe" in affection to influence tourists’ satisfaction.

\subsection{Awe as the Affective Variable}

There are some existing conceptual models that integrate emotional experience with the perceived value of the destination and satisfaction. However, in these models, the emotional variable is only a general concept. As Williams stated, the current emotion studies would not only focusing on how emotions impact on individual behavior, but would further focus on what factors motivate an individual to produce different discrete emotions and how these discrete emotions impact on the individual behavior [20].

Awe is a complex emotion that is particularly relevant to tourism [5]. Awe can lead tourists to feel a strong connection to the surrounding environment and can lead to a desire to prolong, memorize, and relive the travel experience. Moreover, awe prompts tourists to generate positive attitude. Keltner and Haidt adopted the prototype approach to define the emotion of awe [21]. They proposed that awe is a complex emotion that includes confusion, wonder, fear, and a feeling of humility. When the tourist encounters stimuli from natural wonders, divine religion, authority figures, great art, and other external environments, they will experience awe.

\section{Hypotheses and the Conceptual Model}

Coghlan et al. incorporated the concept of awe into tourism research and stated that the emotion of awe can be combined with other relevant variables to build a comprehensive research framework [22]. Therefore, this study considered the tourists' perceived value of the destination as a cognitive factor and focused on the emotion of awe as an affective factor, and integrated these two factors in a comprehensive model of satisfaction.

\subsection{Perceived Value of the Destination and Its Antecedents}

Early scholars believed that the perceived value of a construct resulted from the comparison of gains and losses, which represent quality and price, respectively [23]. Perceived value has a positive correlation with benefits and a negative correlation with the payment of costs. This "get versus give" viewpoint has been adopted by many scholars [24]. Oh reported that, in tourism services, the perceived value of the destination is the cognitive comparison between travel quality and travel costs (including non-monetary costs) and is positively correlated with travel quality and negatively correlated with travel costs [25]. Travel quality is mainly reflected in the perception of the natural and cultural attributes of the tourism destination.

Tourists are attracted to Tibet mainly due to its unique natural scenery and cultural elements. Moreover, the natural environment and the religious atmosphere constitute the major tourism destination image in Tibet tourism. Therefore, in this study, we hypothesized that the natural environment (functional attribute), religious atmosphere (cultural attribute), and the monetary costs would be the main factors that affected the tourists' perceived value of the destination. Specifically, we hypothesized that the monetary cost would be negatively correlated with perceived value (Hypothesis 1 (H1)), the natural environment would be positively correlated with perceived value (H2), and the religious atmosphere would be positively correlated with perceived value (H3).

\subsection{Emotion of Awe and Its Antecedents}

According to Keltner \& Haidt's Prototype Theory of Awe [21], physical and cultural factors may induce the emotion of awe. In Tibet tourism, the physical factors include glaciers, high altitude, and other unusual features of the natural environment, and the cultural factors include the gods that are worshipped, sacred ceremonies, and other religious scenes. There are two main conditions required to generate awe. The first is the perception of vastness [26]. Awe is the powerful psychological impact that individuals experience when are faced with a grand scene, a powerful force, etc. The second condition is the need for accommodation [27]. An individual will have a 
schema-changing experience when they are in a shocking environment that generates a sense of self-insignificance.

Tibet has a fantastic natural environment and a strong religious atmosphere that naturally fulfills the environmental conditions to induce awe. In environmental psychology, Russell and Mehrabian found that people are more easily to arouse emotions when received strong environmental stimuli [28]. Thus, based on the specific context of Tibet, we hypothesized that the natural environment would be positively correlated with the emotion of awe (H4) and the religious atmosphere would be positively correlated with the emotion of awe (H5).

\subsection{The Relations between Perceived Value, Awe, and Satisfaction}

Wirtz et al. reported that satisfaction is influenced by both cognitive and affective components [9]. Chen and Chen stated that the higher the perceived value of the destination, the stronger the satisfaction [29]. Wirtz and Bateson and others have proposed that adding emotional variables into the pure cognitive approach to defining consumer satisfaction would increase the accuracy with which consumer satisfaction could be predicted [30]. Yuksel and Yuksel pointed out that positive emotions can significantly improve customer satisfaction [31]. Awe is a positive emotion and may also increase customer satisfaction. Therefore, we hypothesized that the perceived value of the destination would be positively correlated with tourist satisfaction (H6) and the emotion of awe would be positively correlated with satisfaction (H7).

In clarifying the relation between cognition and affection, Lazarus proposed that individual emotions are produced after cognitive evaluation in the surrounding environmental conditions, and that these emotions subsequently impacted behavior [32]. Otto and Ritchie found that specific emotional variables mediated the relation between functional perception and satisfaction [33]. Therefore, we hypothesized that the emotion of awe would mediate the relation between perceived value of the destination and satisfaction (H8).

A conceptual model that includes all study hypotheses is shown in Figure 1.

\section{Research Methods}

\subsection{Research Design}

78 members from one Chinese Tibet travel club were randomly selected and were invited to complete a pretest questionnaire. In the questionnaire, the 7-point Likert Scale were used to evaluate the natural environment, religious atmosphere, the monetary costs, perceived value of the destination, and tourists' satisfaction (1 represents strongly disagree, 7 represents strongly agree). The Semantic Differential Scale was used to evaluate the emotion of awe (1 represents a negative anchor word, 7 represents a positive anchor word). The items evaluating perceptions of the natural environment and religious atmosphere were developed with reference to the Prototype Approach of Awe, which identifies the conditions that evoke the emotion of awe [21]. Two dimensions, external vastness and internal smallness, were used to evaluate the perceptions of natural environment and religious atmosphere. The items to evaluate awe were based on the framework for awe in tourism research [22]. The items to evaluate all other variables (monetary costs, perceived value of the destination, and tourists' satisfaction) were

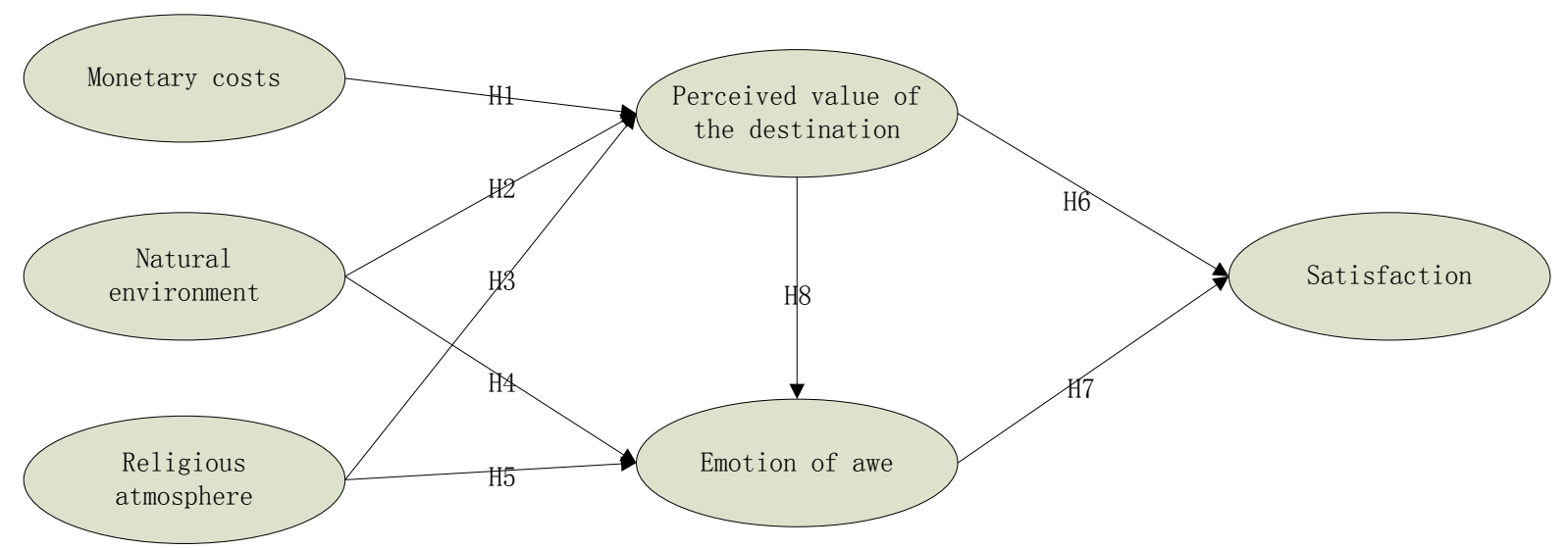

Figure 1. The conceptual model. 
based on the author's mature scale in tourism research [7]. The pretest results were used to refine the study questionnaire by deleting the items that negatively contributed to Cronbach's $\alpha$ and the items that had a low item-to-total correlation coefficient. In the formal test, participants were recruited using the snowball method. Members from the Tibet travel club and Tibet travel online community were randomly invited to fill out the refined questionnaire and asked to invite similar tourists to take part in the survey. During the over one month data collection period, 385 participants successfully completed the questionnaire. The demographic characteristics of the participants are stated in Table 1.

\subsection{Reliability and Validity Check}

According to Anderson and Gerbing [34], the reliability and validity of the questionnaire items were evaluated using confirmatory factor analysis. Analysis was performed using Mplus 7 (Muthen \& Muthen, 2010). The data fit te model well $\left(\chi^{2}=690.963(\mathrm{df}=282, p<0.001)\right.$; CFI (Comparative Fit Index) $=0.927$; TLI (Tucker Lewis Index $=0.916$; SRMR (Standardized Root Mean Square Residual) $=0.046$; RMSEA (Root Mean Square Error Of Approximation) $=0.061$. According to Hu and Bentler (1999), the model fit indexes $\left(\chi^{2} / \mathrm{df}=2.45\right.$; NFI and TLI > 0.90; SRMR and RMSEA < 0.08) indicated that the model was acceptable.

The reliability and convergent validity of the questionnaire items were evaluated using construct reliability (Table 2). The construct reliability (CR) was $>0.7$, indicating good reliability. Each observed variable and latent variable had a corresponding standardized factor loading $(\lambda)>0.6$ and a significant t-value $(p<0.001)$, indicating that the measurement had validity. The average variance extracted (AVE) from each measurement was $>0.5$, indicating good convergent validity. Moreover, the AVE was also greater than the square of the correlation for each latent variable. So the discriminant validity was good enough (Table 3).

Table 1. The demographic characteristics of participants.

\begin{tabular}{|c|c|c|c|}
\hline & & $\mathbf{N}$ & $\%$ \\
\hline \multirow[t]{2}{*}{ Gender } & Male & 237 & 61.6 \\
\hline & Female & 148 & 38.4 \\
\hline \multirow[t]{5}{*}{ Age } & $\leq 20$ years & 6 & 1.6 \\
\hline & 21 - 30 years & 243 & 63.1 \\
\hline & 31 - 40 years & 114 & 29.6 \\
\hline & 41 - 50 years & 18 & 4.7 \\
\hline & $\geq 51$ years & 4 & 1.0 \\
\hline \multirow[t]{3}{*}{ Highest level of education } & High school & 1 & 0.3 \\
\hline & College & 186 & 48.3 \\
\hline & Graduate school & 198 & 51.4 \\
\hline \multirow[t]{5}{*}{ Income before tax } & $\leq 2000 \mathrm{RMB}$ & 33 & 8.6 \\
\hline & 2001 - 5000 RMB & 84 & 21.8 \\
\hline & 5001 - 8000 RMB & 177 & 46.0 \\
\hline & 8001 - 15,000 RMB & 54 & 14.0 \\
\hline & $\geq 15001 \mathrm{RMB}$ & 37 & 9.6 \\
\hline \multirow[t]{4}{*}{ Frequency of travel in the last 3 years ${ }^{\mathrm{a}}$} & None & 4 & 1.0 \\
\hline & 1 - 2 times per year & 244 & 63.4 \\
\hline & 3 - 5 times per year & 120 & 31.2 \\
\hline & $\geq 5$ times per year & 17 & 4.4 \\
\hline \multirow[t]{4}{*}{ Buddhism belief } & No religion & 44 & 11.4 \\
\hline & Occasionally visit Buddha Hall & 251 & 65.2 \\
\hline & Often pray to Buddha & 77 & 20.0 \\
\hline & Buddhist & 13 & 3.4 \\
\hline
\end{tabular}

${ }^{\mathrm{a}}$ Restricted to travel $\geq 3$ days duration. 
Table 2. The reliability and convergent validity of the questionnaire items.

\begin{tabular}{|c|c|c|c|c|c|}
\hline Latent variable & Item & $\lambda$ & t-value & $\mathbf{C R}$ & AVE \\
\hline \multirow{6}{*}{$\begin{array}{c}\text { Natural } \\
\text { environment }^{\mathrm{a}}\end{array}$} & EV1: In Tibet I feel mountains are magnificent & 0.837 & 38.856 & 0.90 & 0.59 \\
\hline & EV2: In Tibet I feel the natural force is powerful & 0.806 & 32.851 & & \\
\hline & EV3: In Tibet I feel period of landforms formed is long & 0.792 & 31.060 & & \\
\hline & EV4: The natural environment makes me feel small & 0.761 & 27.426 & & \\
\hline & EV5: The natural environment makes me feel that my force is weak & 0.724 & 18.858 & & \\
\hline & EV6: I feel I need to be humble to nature & 0.694 & 17.391 & & \\
\hline \multirow{4}{*}{$\begin{array}{l}\text { Religious } \\
\text { atmosphere }^{\mathrm{a}}\end{array}$} & RL1: In Tibet I feel that the pilgrimage scenes are great & 0.783 & 26.336 & 0.90 & 0.69 \\
\hline & RL2: In Tibet I feel that the Buddha is noble & 0.846 & 36.714 & & \\
\hline & RL3: Compared with the Buddha, I feel people are small & 0.847 & 42.777 & & \\
\hline & RL4: I feel I need to be humble to the Buddha & 0.840 & 43.532 & & \\
\hline \multirow{4}{*}{$\begin{array}{l}\text { Monetary } \\
\operatorname{costs}^{\mathrm{a}}\end{array}$} & PC1: The total travelling expenditure cost a lot & 0.686 & 9.213 & 0.80 & 0.51 \\
\hline & PC2: The round-trip transportation price is very expensive & 0.636 & 8.646 & & \\
\hline & PC3: The accommodation price in Tibet is very expensive & 0.808 & 15.212 & & \\
\hline & PC4: The catering price in Tibet is very expensive & 0.711 & 14.530 & & \\
\hline \multirow{3}{*}{$\begin{array}{l}\text { Perceived value } \\
\text { of the destination }\end{array}$} & PV1: The overall value of the travel is very wonderful & 0.842 & 32.032 & 0.83 & 0.62 \\
\hline & PV2: Compared with my pay, I gain a lot from this travel & 0.776 & 24.679 & & \\
\hline & PV3: The richness of my experience from this travel is very much & 0.746 & 24.890 & & \\
\hline \multirow{6}{*}{ Emotion of awe $\mathrm{b}^{\mathrm{b}}$} & AW1: In Tibet my feeling is (calm-shock) & 0.775 & 28.669 & 0.89 & 0.59 \\
\hline & AW2: In Tibet my feeling is (peaceful-surprised). & 0.723 & 25.152 & & \\
\hline & AW3: In Tibet my feeling is (sleepy-excited) & 0.705 & 18.524 & & \\
\hline & AW4: In Tibet my feeling is (arrogant-humble) & 0.795 & 28.374 & & \\
\hline & AW5: In Tibet my feeling is (slighting-revered) & 0.852 & 40.642 & & \\
\hline & AW6: In Tibet my feeling is (careless-respectful) & 0.739 & 24.286 & & \\
\hline \multirow{3}{*}{ Satisfaction $^{\mathrm{a}}$} & SA1: It is wise to choose this trip & 0.863 & 51.955 & 0.87 & 0.69 \\
\hline & SA2: Travel in Tibet makes me feel satisfied & 0.790 & 27.776 & & \\
\hline & SA3: This travel experience is what I need and want & 0.839 & 39.162 & & \\
\hline
\end{tabular}

${ }^{a}$ Item rated on a 7-point Likert Scale from 1 (strongly disagree) to 7 (strongly agree). ${ }^{\mathrm{b}}$ Item rated on the Semantic Differential Scale from -3 (negative anchor word) to +3 (positive anchor word).

Table 3. The discriminant validity of the latent variable.

\begin{tabular}{|c|c|c|c|c|c|c|}
\hline Latent variable & 1 & 2 & 3 & 4 & 5 & 6 \\
\hline 1. Natural environment & $0.59^{\mathrm{a}}$ & & & & & \\
\hline 2. Religious atmosphere & $0.551^{\mathrm{b}}$ & 0.69 & & & & \\
\hline 3. Monetary costs & 0.000 & 0.000 & 0.51 & & & \\
\hline 4. Perceived value of the destination & 0.469 & 0.301 & 0.000 & 0.62 & & \\
\hline 5. Emotion of awe & 0.524 & 0.424 & 0.005 & 0.486 & 0.59 & \\
\hline 6. Satisfaction & 0.473 & 0.276 & 0.008 & 0.832 & 0.679 & 0.69 \\
\hline
\end{tabular}

${ }^{\mathrm{a}}$ The AVE is on the diagonal line. ${ }^{\mathrm{b}}$ The square of the correlation for each latent variable is below the diagonal line. 


\subsection{Hypotheses Testing}

Mplus output for the model fit indices were as follows: $\chi^{2}=700.810(\mathrm{df}=286, p<0.001)$; CFI $=0.926$; $\mathrm{TLI}=$ 0.916; SRMR $=0.047$; RMSEA $=0.061$. According to Hu and Bentler [35], the model fit indexes $\left(\chi^{2} / \mathrm{df}=2.45\right.$, NFI and TLI $>0.90$, and SRMR and RMSEA $<0.08$ ) indicated that the overall model fit was acceptable (Figure 2).

Dashed lines represent path coefficients that were not significant $(p>0.05)$. All path coefficients are standardized. All abbreviations used in the figure references to Table 1 for the meanings.

The perception of the natural environment was positively correlated with perceived value of the destination $(\gamma=$ $0.643, p<0.001)$, the perception of the religious atmosphere had no significant correlation with perceived value $(\gamma$ $=0.045, p=0.651)$, and monetary cost had no significant correlation with perceived value $(\gamma=-0.049, p=0.353)$. The perceived value of the destination was significantly affected by functional value, but not by social or monetary value. Namely, the data support $\mathrm{H} 2$ but do not support $\mathrm{H} 1$ or $\mathrm{H} 3$.

The emotion of awe was affected by the perception of both the natural environment and the religious atmosphere, with path coefficients of $\gamma=0.294(p<0.01)$ and $\gamma=0.224(p<0.01)$, respectively. The data therefore support $\mathrm{H} 4$ and $\mathrm{H} 5$.

For the relations between perceived value, emotion of awe, and tourist satisfaction, perceived value was positively correlated with tourist satisfaction with a path coefficient of $\beta=0.661(p<0.001)$, the emotion of awe was positively correlated with tourist satisfaction with a path coefficient of $\beta=0.355(p<0.001)$, and perceived value was positively correlated with the emotion of awe with a path coefficient of $\beta=0.384(p<0.001)$. The mediating effect of emotion of awe on the relation between perceived value and tourist satisfaction was $0.136(p<0.001)$. This indicates that the emotion of awe was a partial mediator of the relation between perceived value and tourist satisfaction. Thus, H6, H7, and H8 are all supported.

\section{Discussions and Conclusion}

\subsection{Discussions}

The empirical results show that the main factor affecting tourists' perceived value of Tibet as a destination was their perception of the natural attributes of the destination. By contrast, the cultural attributes and the monetary

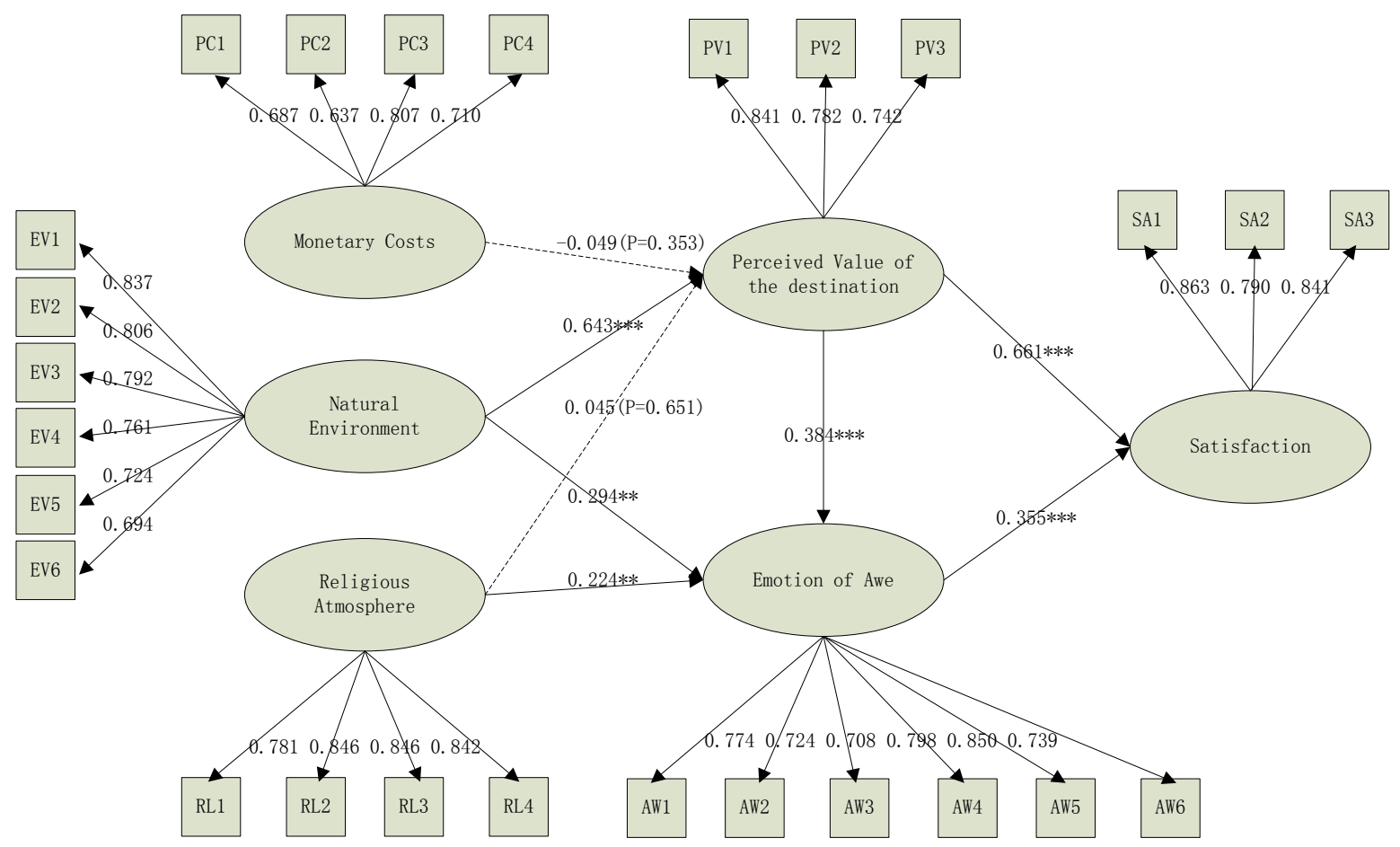

Figure 2. Data fitting model. ${ }^{*} p<0.05$, two-tailed test; ${ }^{* *} p<0.01$, two-tailed test; ${ }^{* * *} p<0.001$, two-tailed test. 
costs did not significantly influence the perceived value of the destination. In this study, the perceived religious atmosphere did not significantly affect the perceived value of the destination. This may be due to the survey sample. The sample was made up of Chinese individuals that most of them are lack of religious faith. Only $3.4 \%$ of the study sample was Buddhist. The fact that most participants in the study sample were not religious may have weakened the relation between religious atmosphere and the perceived value of the destination in this study.

Otherwise, due to the diversity of travel costs, in this study the impact from monetary costs on the perceived value of the destination is not significant yet. Unlike most goods, which have a fixed price range, the price of tourism products is influenced by many factors including the quality of the hotels, the quality and volume of food and beverage consumption, and the richness of the program contents. Tourists have differing consumption, and the perceived value of the destination is not easily judged by the monetary costs if only considering the impaction of price. In a similar study, Gallarza and Saura also found that the construct of monetary costs had no significant effect on the perceived value of the destination [7]. In addition, perceived value was positively correlated with tourist satisfaction, suggesting that tourists' satisfaction largely came from perceived value in the tourism process.

Our results also show that the emotion of awe experienced by tourists in Tibet was generated by both the natural environment and the religious atmosphere. The natural environment and the religious atmosphere gave tourists a sense of external vastness and self-insignificance, and this stimulates awe. Otto and Ritchie believed that the quality of individual travel experience is related to a specific emotion, and a high-quality travel experience is more likely to arouse positive emotions [33]. When tourists perceive a high value, they would experience a high level of positive emotions. Awe is a positive emotion, and the tourism environment can make tourists feel awe.

In contrast to previous studies that merely considered a single perspective - either the cognitive perspective (i.e. the relation between perceived value and satisfaction) or the affective perspective (i.e. the relation between general emotion and satisfaction) - this study considered the dual impact of cognition and affection on satisfaction. In this study, tourists' satisfaction was not only affected by the perceived value of the destination at the cognitive level, but also by the emotion of awe at the affective level. Therefore, the results of this study can fully explain how tourists' satisfaction is driven by cognitive and emotional factors. In addition, most previous studies have only considered general positive or negative emotions as the affective variable, without any in-depth discussion of the specific emotions that tourists may have experienced [36]. In the context of Tibet tourism, this study found that the natural attributes and cultural attributes of the Tibet tourism environment made tourists feel awe, and thus promoted tourists' satisfaction.

\subsection{Conclusion}

Based on the dual perspective of cognition and affection, this study built an integrated model to explain the impact of cognitive and affective factors on tourists' satisfaction. This study created a questionnaire that was used to collect data from tourists in Tibet and applied the Structural Equation Modeling method to test the conceptual model. The empirical results indicated that, in Tibet, the tourist's emotion of awe was produced by two environmental factors, namely, the natural environment and the religious atmosphere. The emotion of awe further promoted tourists' satisfaction. The environmental factors and monetary costs had an impact on the perceived value of the destination. Perceived value had been one of the core constructs in the study of consumer behavior in the past 30 years, and was significantly and positively correlated with tourists' satisfaction [37]. The relations between perceived value of the destination and satisfaction were also verified in this study. In addition, the results of this study indicated that perceived value of the destination indirectly affected tourists' satisfaction through the intermediary role of the emotion of awe. This was consistent with the theoretical path of cognitive-emotional meaning action in emotional psychology.

In summary, this study made two major contributions to the field. The cognitive-affective nature of satisfaction was used to build an integrated model that explains tourists' satisfaction from a dual perspective, furthering existing literature that considerdonly a single perspective. In addition, this study found that the emotion of awe was one kind of positive emotion that improved tourists' satisfaction. The empirical data proved that an integrated model could provide a comprehensive explanation of tourists' satisfaction.

\subsection{Suggestions}

Future studies should break down the objects of tourism consumption. Tourism consumption is a complex, integrated consumer behavior that involved the consumption of tangible and intangible products. The objects from 
tourists' satisfaction and loyalty could be beauty spots, the travel agencies, the service facilities and staff, the bed and board, etc. For these elements, there must be some factors that influenced satisfaction and loyalty at either the cognitive or the affective level. In addition, future studies should research the impact of other discrete emotions on tourists' satisfaction and loyalty. Different tourism destinations had different characteristics. In addition to the emotion of awe, tourists might also experience well-being, entertainment, or other positive emotions. Dick and Basu indicated that if customers underwent a notable emotional experience, they would be more loyal [3]. Thus, future studies should subdivide tourism consumption objects and consider other discrete emotions to investigate how to raise tourists' satisfaction and loyalty at both the cognitive and the affective level.

\section{Research Foundation}

This study was funded by MOE (Ministry of Education in China) Project of Humanities and Social Sciences (Project No.15XJC790008).

\section{References}

[1] Cronin Jr., J.J., Brady, M.K. and Hult, G.T.M. (2000) Assessing the Effects of Quality, Value, and Customer Satisfaction on Consumer Behavioral Intentions in Service Environments. Journal of Retailing, 76, 193-218. http://dx.doi.org/10.1016/S0022-4359(00)00028-2

[2] Chi, C.G.-Q. and Qu, H. (2008) Examining the Structural Relationships of Destination Image, Tourist Satisfaction and Destination Loyalty: An Integrated Approach. Tourism Management, 29, 624-636. http://dx.doi.org/10.1016/j.tourman.2007.06.007

[3] Dick, A.S. and Basu, K. (1994) Customer Loyalty: Toward an Integrated Conceptual Framework. Journal of the Academy of Marketing Science, 22, 99-113. http://dx.doi.org/10.1177/0092070394222001

[4] Lane, B. (1994) What Is Rural Tourism? Journal of Sustainable Tourism, 2, 7-21. http://dx.doi.org/10.1080/09669589409510680

[5] Shiota, M.N., Keltner, D. and Mossman, A. (2007) The Nature of Awe: Elicitors, Appraisals, and Effects on SelfConcept. Cognition \& Emotion, 21, 944-963. http://dx.doi.org/10.1080/02699930600923668

[6] Decrop, A. (1999) Tourists’ Decision-Making and Behavior Processes. In: Pizam, A. and Mansfeld, Y., Eds., Consumer Behavior in Travel and Tourism, Routledge, New York, 103-133.

[7] Gallarza, M.G. and Gil Saura, I. (2006) Value Dimensions, Perceived Value, Satisfaction and Loyalty: An Investigation of University Students' Travel Behaviour. Tourism Management, 27, 437-452. http://dx.doi.org/10.1016/j.tourman.2004.12.002

[8] Castro, C.B., Martín Armario, E. and Martín Ruiz, D. (2007) The Influence of Market Heterogeneity on the Relationship between a Destination’s Image and Tourists’ Future Behaviour. Tourism Management, 28, 175-187. http://dx.doi.org/10.1016/j.tourman.2005.11.013

[9] Wirtz, J., Mattila, A.S. and Tan, R.L. (2000) The Moderating Role of Target-Arousal on the Impact of Affect on Satisfaction-An Examination in the Context of Service Experiences. Journal of Retailing, 76, 347-365. http://dx.doi.org/10.1016/S0022-4359(00)00031-2

[10] Phillips, D.M. and Baumgartner, H. (2002) The Role of Consumption Emotions in the Satisfaction Response. Journal of Consumer Psychology, 12, 243-252. http://dx.doi.org/10.1207/S15327663JCP1203_06

[11] Walsh, G., Shiu, E., Hassan, L.M., Michaelidou, N. and Beatty, S.E. (2011) Emotions, Store-Environmental Cues, Store-Choice Criteria, and Marketing Outcomes. Journal of Business Research, 64, 737-744. http://dx.doi.org/10.1016/j.jbusres.2010.07.008

[12] Lee, J. and Guo, Y.Y. (2008) Materialism and the Relevant Studies. Advances in Psychological Science, 16, 637-643.

[13] Piaget, J. (1981) Intelligence and Affectivity: Their Relationship during Child Development. Translated and Edited by Brown, T.A. and Kaegi, C.E., Annual Reviews, Oxford.

[14] Lemerise, E.A. and Arsenio, W.F. (2000) An Integrated Model of Emotion Processes and Cognition in social Information Processing. Child Development, 71, 107-118. http://dx.doi.org/10.1111/1467-8624.00124

[15] Gray, J.R., Braver, T.S. and Raichle, M.E. (2002) Integration of Emotion and Cognition in the Lateral Prefrontal Cortex. Proceedings of the National Academy of Sciences of the United States of America, 99, 4115-4120. http://dx.doi.org/10.1073/pnas.062381899

[16] Mano, H. and Oliver, R.L. (1993) Assessing the Dimensionality and Structure of the Consumption Experience: Evaluation, Feeling, and Satisfaction. Journal of Consumer Research, 20, 451-466. http://dx.doi.org/10.1086/209361 
[17] Van Dolen, W., De Ruyter, K. and Lemmink, J. (2004) An Empirical Assessment of the Influence of Customer Emotions and Contact Employee Performance on Encounter and Relationship Satisfaction. Journal of Business Research, 57, 437-444. http://dx.doi.org/10.1016/S0148-2963(02)00277-1

[18] Bigne, J.E., Andreu, L. and Gnoth, J. (2005) The Theme Park Experience: An Analysis of Pleasure, Arousal and Satisfaction. Tourism Management, 26, 833-844. http://dx.doi.org/10.1016/j.tourman.2004.05.006

[19] del Bosque, I.R. and Martin, H.S. (2008) Tourist Satisfaction a Cognitive-Affective Model. Annals of Tourism Research, 35, 551-573. http://dx.doi.org/10.1016/j.annals.2008.02.006

[20] Williams, P. (2014) Emotions and Consumer Behavior. Journal of Consumer Research, 40, 8-11. http://dx.doi.org/10.1086/674429

[21] Keltner, D. and Haidt, J. (2003) Approaching Awe, a Moral, Spiritual, and Aesthetic Emotion. Cognition \& Emotion, 17, 297-314. http://dx.doi.org/10.1080/02699930302297

[22] Coghlan, A., Buckley, R. and Weaver, D. (2012) A Framework for Analysing Awe in Tourism Experiences. Annals of Tourism Research, 39, 1710-1714. http://dx.doi.org/10.1016/j.annals.2012.03.007

[23] Parasuraman, A. (1997) Reflections on Gaining Competitive Advantage through Customer Value. Journal of the Academy of Marketing Science, 25, 154-161. http://dx.doi.org/10.1007/BF02894351

[24] Lovelock, C. (2011) Services Marketing (7/e). Pearson, New York.

[25] Oh, H. (2000) The Effect of Brand Class, Brand Awareness, and Price on Customer Value and Behavioral Intentions. Journal of Hospitality \& Tourism Research, 24, 136-162. http://dx.doi.org/10.1177/109634800002400202

[26] Bonner, E.T. and Friedman, H.L. (2011) A Conceptual Clarification of the Experience of Awe: An Interpretative Phenomenological Analysis. The Humanistic Psychologist, 39, 222-235. http://dx.doi.org/10.1080/08873267.2011.593372

[27] Sundararajan, L. (2002) Religious Awe: Potential Contributions of Negative Theology to Psychology, "Positive” or Otherwise. Journal of Theoretical and Philosophical Psychology, 22, 174-197. http://dx.doi.org/10.1037/h0091221

[28] Russell, J.A. and Mehrabian, A. (1978) Approach-Avoidance and Affiliation as Functions of the Emotion-Eliciting Quality of an Environment. Environment and Behavior, 10, 355-387. http://dx.doi.org/10.1177/0013916578103005

[29] Chen, C.-F. and Chen, F.-S. (2010) Experience Quality, Perceived Value, Satisfaction and Behavioral Intentions for Heritage Tourists. Tourism Management, 31, 29-35. http://dx.doi.org/10.1016/j.tourman.2009.02.008

[30] Wirtz, J. and Bateson, J.E. (1999) Consumer Satisfaction with Services: Integrating the Environment Perspective in Services Marketing into the Traditional Disconfirmation Paradigm. Journal of Business Research, 44, 55-66. http://dx.doi.org/10.1016/S0148-2963(97)00178-1

[31] Yuksel, A. and Yuksel, F. (2007) Shopping Risk Perceptions: Effects on Tourists' Emotions, Satisfaction and Expressed Loyalty Intentions. Tourism Management, 28, 703-713. http://dx.doi.org/10.1016/j.tourman.2006.04.025

[32] Lazarus, R.S. (1991) Emotion and Adaptation. Oxford University Press, New York.

[33] Otto, J.E. and Ritchie, J. (1996) The Service Experience in Tourism. Tourism Management, 17, 165-174. http://dx.doi.org/10.1016/0261-5177(96)00003-9

[34] Anderson, J.C. and Gerbing, D.W. (1988) Structural Equation Modeling in Practice: A Review and Recommended Two-Step Approach. Psychological Bulletin, 103, 411-423. http://dx.doi.org/10.1037/0033-2909.103.3.411

[35] Hu, L.T. and Bentler, P.M. (1999) Cutoff Criteria for Fit Indexes in Covariance Structure Analysis: Conventional Criteria versus New Alternatives. Structural Equation Modeling: A Multidisciplinary Journal, 6, 1-55. http://dx.doi.org/10.1080/10705519909540118

[36] Lee, J.-S., Lee, C.-K. and Choi, Y. (2011) Examining the Role of Emotional and Functional Values in Festival Evaluation. Journal of Travel Research, 50, 685-696. http://dx.doi.org/10.1177/0047287510385465

[37] Gallarza, M.G., Gil-Saura, I. and Holbrook, M.B. (2011) The Value of Value: Further Excursions on the Meaning and Role of Customer Value. Journal of Consumer Behaviour, 10, 179-191. http://dx.doi.org/10.1002/cb.328 